\title{
TECHNO-ECONOMIC EVALUATION OF NITROCELLULOSE PRODUCTION FROM PALM OIL EMPTY FRUIT BUNCHES
}

\author{
Jabosar Ronggur Hamonangan Panjaitan ${ }^{*}$, and Misri Gozan² \\ ${ }^{1}$ Chemical Engineering Program, Institut Teknologi Sumatera, Lampung, Indonesia, Tel: +62 81266400963 , \\ e-mail: jabosar.panjaitan@tse.itera.ac.id. (*Corresponding Author) \\ ${ }^{2}$ Chemical Engineering Department, Faculty of Engineering, Universitas Indonesia, Depok, Indonesia, \\ Tel: +62 8578117 6292, e-mail:misrigozan@gmail.com.
}

Received Date: August 3, 2020; Revised Date: June 10, 2021; Acceptance Date: November 18, 2021

\begin{abstract}
Nitrocellulose is a cellulose derivative that has many potential applications. Nitrocellulose can be made through nitration reactions by reacting cellulose and nitric acid at low temperatures. Cellulose can be obtained from lignocellulose biomass such as palm oil empty fruit bunches (POEFBs). In this study, techno-economic evaluation of nitrocellulose production from POEFBs was investigated with various types of alkaline and acid pretreatments. Pretreatment of POEFBs with alkaline and acid was used to purify cellulose fraction as raw material for nitrocellulose. The combination process of POEFBs pretreatment with alkaline and acid can be classified into 4 process routes such as ammonium hydroxide and sulfuric acid pretreatment (Route-1), ammonium hydroxide and acetic acid pretreatment (Route-2), sodium hydroxide and sulfuric acid pretreatment (Route-3), and sodium hydroxide and acetic acid pretreatment (Route-4). The results showed that ammonium hydroxide and sulfuric acid pretreatment (Route-1) was the most profitable route to produce nitrocellulose. Economic parameter values such as return of investment (ROI), payback period (PBP), net present value (NPV) and internal rate of return (IRR) from ammonium hydroxide and sulfuric acid pretreatment (Route-1) were $11.49 \%$, 5.85 years, US\$ 442,427 and $13.35 \%$.
\end{abstract}

Keywords: Economic evaluation, Nitrocellulose, Palm oil

\section{Introduction}

Indonesia has the largest palm oil plantation in the world that has around 11.6 million hectares and produces 33.5 million tons of palm oil in $2016^{1}$. Along with the increasing amount of palm oil production in Indonesia, the amount of palm oil waste was also increases. Oil palm empty bunches (POEFB) are one of the wastes that produced around $22-23 \%$ from fresh fruit bunches (FFB). Palm oil industry will produce POEFBs waste around 1.1 tons for every 1 ton of CPO produced ${ }^{2}$.

POEFBs are lignocellulose biomass that contained 22.8\% lignin, 39.3\% $\alpha$-cellulose and $29.8 \%$ hemicellulose ${ }^{3}$. Cellulose in POEFB can be utilized into products such as polymers, biochemical and biofuel with high selling price, one of them is nitrocellulose. Nitrocellulose can be produced from the reaction between cellulose and nitric acid ${ }^{4}$. Cotton linters usually used as raw material for nitrocellulose production. The application of nitrocellulose for industrial purposes is very broad such as in the plastic industry, paints, adhesives and even used as rocket fuel (propellant). Nitrocellulose as a propellant was applied to Folded Fin Aerial Rocket (FFAR) rockets that used by Indonesia army. FFAR uses double base propellant with its main composition being nitrocellulose and nitroglycerin ${ }^{5}$. In addition, the need for global nitrocellulose is predicted to increase every year. Grand View Research ${ }^{6}$ predicts that the need for nitrocellulose such as printer ink, paint, wood coatings, leather finishes and nail varnishes will increase by $6.1 \%$ from 2018 to 2024 . 
The challenge to produce nitrocellulose from lignocellulose biomass is the purification process of cellulose. Cellulose fraction in biomass fibers must be separated from hemicellulose and lignin. Separation method using alkaline and acid compounds is one of the pretreatments that can be used to purify cellulose effectively. Alkaline used to eliminate lignin, but acid used to remove hemicellulose and lignin. Gozan et al. ${ }^{3}$ performed pretreatment using soaking in aqueous ammonia (SAA) method on POEFBs for 14 hours at $27^{\circ} \mathrm{C}$ resulting in $7 \%$ lignin reduction. Triwahyuni et al. ${ }^{7}$ performed pretreatment on POEFBs using $10 \%$ sodium hydroxide at $150^{\circ} \mathrm{C}$ for 30 minutes resulting in reduction of hemicellulose and lignin compounds in POEFBs by $59 \%$ and $69 \%$. Ying et al. ${ }^{8}$ performed pretreatment on POEFBs using $2 \%$ sulfuric acid at $120^{\circ} \mathrm{C}$ for 60 minutes resulting in a reduction of hemicellulose compounds in POEFBs by $97 \%$. Mouthier et al. ${ }^{9}$ performed pretreatment on corn stover using $30 \%$ acetic acid at $160^{\circ} \mathrm{C}$ for 60 minutes resulting in reduction of hemicellulose and lignin compounds in POEFBs by $75 \%$ and $72 \%$. Therefore, combination of alkaline and acid pretreatment is useful to produce cellulose which become the raw material for nitrocellulose production.

In this study, we investigated the techno-economic evaluation of industrial-scale nitrocellulose production using a combination of various alkaline and acid pretreatments. Economic evaluation of nitrocellulose production will be analyzed by using SuperPro Designer 9.0. Techno-economic evaluation can be a reference to choose the most economical production process in producing nitrocellulose.

\section{Material and Methods}

\section{Process Simulation}

Nitrocellulose production was carried out by various combinations of alkaline (ammonium hydroxide and sodium hydroxide) and acid (sulfuric acid and acetic acid) pretreatment methods. POEFBs pretreatment with alkaline and acid compounds can be classified into 4 process routes, namely ammonium hydroxide and sulfuric acid pretreatment (Route-1), ammonium hydroxide and acetic acid pretreatment (Route-2), sodium hydroxide and sulfuric acid pretreatment (Route-3), and sodium hydroxide and acetic acid pretreatment (Route-4). The operating condition for each type of pretreatment can be seen in table 1. Operating condition of nitrocellulose production are based on Setiadi et al. ${ }^{10}$ which carried out at $5^{\circ} \mathrm{C}$ for 90 minutes with a ratio of POEFBs and acid solutions around 1:20.

Table 1. Operating Condition for POEFBs Treatment

\begin{tabular}{|c|c|c|c|c|c|}
\hline Pretreatment & $\begin{array}{l}\text { Temperature } \\
\left({ }^{\circ} \mathrm{C}\right)\end{array}$ & $\begin{array}{l}\text { Solid to } \\
\text { Liquid } \\
\text { Ratio }\end{array}$ & $\begin{array}{l}\text { Reaction } \\
\text { Time } \\
\text { (hour) }\end{array}$ & $\begin{array}{l}\text { Concentration } \\
(\%)\end{array}$ & Reference \\
\hline $\begin{array}{l}\text { Ammonium } \\
\text { hydroxide }\end{array}$ & 27 & $1: 6$ & 14 & 13.13 & {$[3]$} \\
\hline $\begin{array}{l}\text { Sodium } \\
\text { hydroxide }\end{array}$ & 150 & $1: 5$ & 0.5 & 10 & [7] \\
\hline Sulfuric acid & 120 & $1: 12$ & 1 & 2 & [8] \\
\hline Acetic acid & 160 & $1: 13.3$ & 1 & 30 & [9] \\
\hline
\end{tabular}

Ammonium hydroxide pretreatment was carried out by a simple immersion method at room temperature. POEFBs was soaked at soaking tank with ammonium hydroxide solution for 14 hours. After that, ammonium hydroxide was recycled from the 
pretreatment product using evaporator. Next, solid product was washed and separated by filtration. On the other side, the pretreatment process using sodium hydroxide is carried out at $150^{\circ} \mathrm{C}$ using high pressure vessel for 0.5 hour. Solid product from sodium hydroxide pretreatment was washed with water.

Pretreatment using alkaline was followed by acid pretreatment. Sulfuric acid is a cheap strong acid that commonly used as a catalyst in lignocellulose hydrolysis reaction and nitrocellulose production. Sulfuric acid pretreatment was done using high pressure vessel at $120^{\circ} \mathrm{C}$ for 1 hour. Product from sulfuric acid pretreatment was cooled with cooler until room temperature. After that, the product from sulfuric acid pretreatment enter the nitration reactor. On the other side, acetic acid pretreatment has many advantages in biomass delignification and hydrolysis reaction because the low boiling point of acetic acid $\left( \pm 118^{\circ} \mathrm{C}\right)$ which can be recycled through acid recovery process. Acetic acid pretreatment was done using high pressure vessel at $160^{\circ} \mathrm{C}$ for 1 hour. Next, solid product from sodium hydroxide pretreatment was washed with water then enter the nitration reactor. The flow chart of various pretreatment methods can be seen in Figure 1.

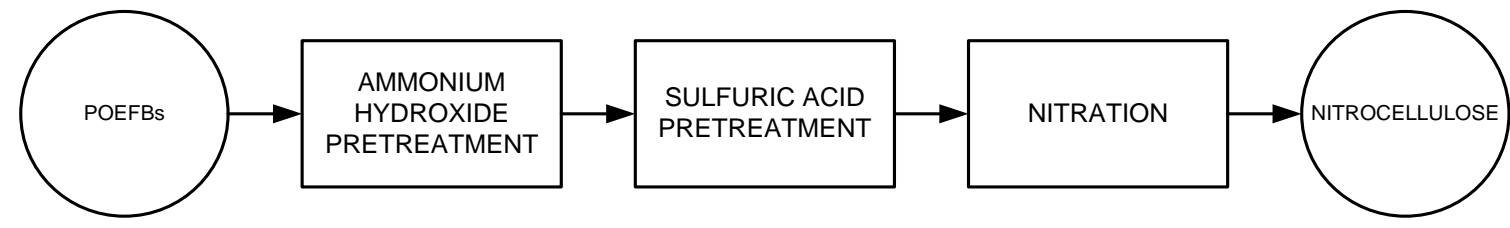

(a)

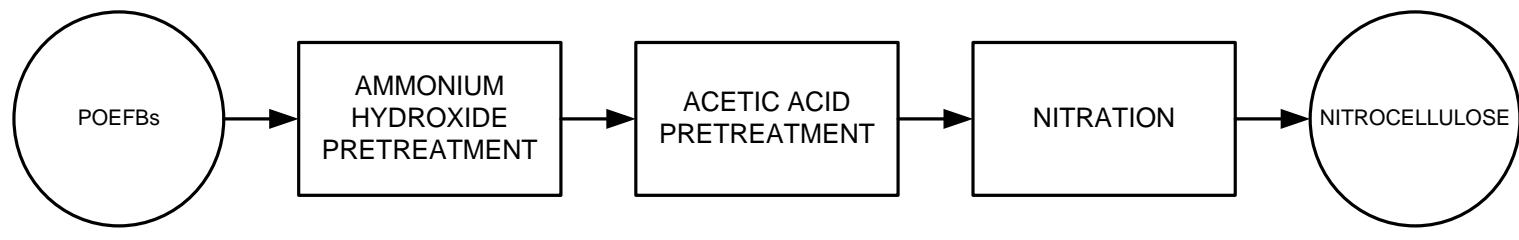

(b)

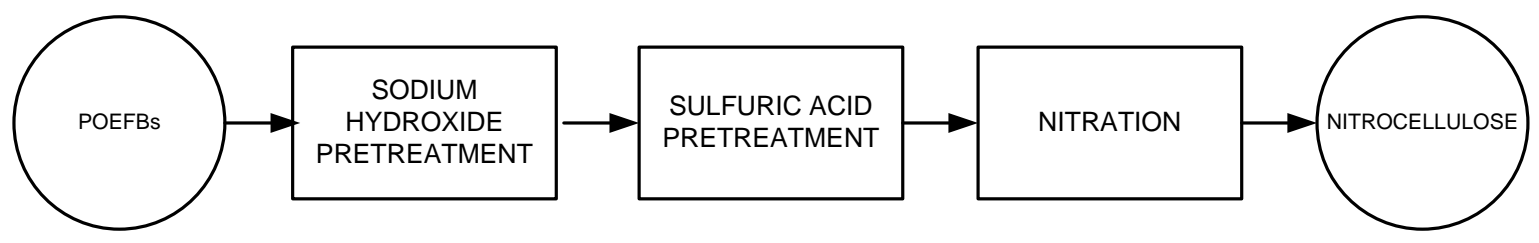

(c)

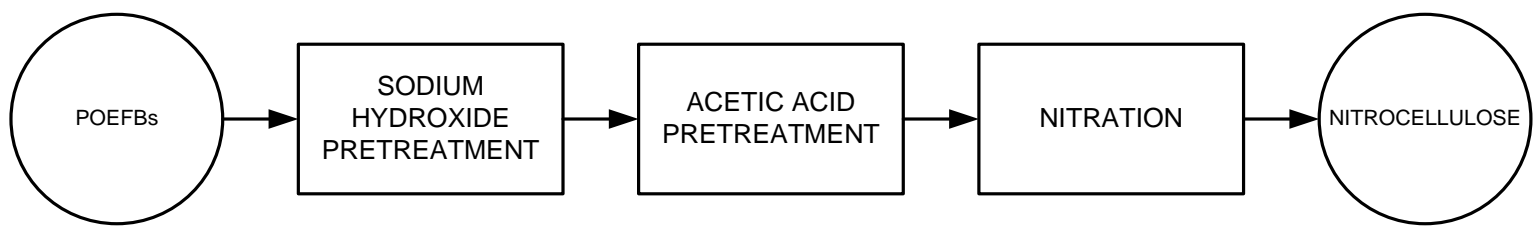

(d)

Figure 1. Nitrocellulose production using various pretreatment combinations; (a) ammonium hydroxide and sulfuric acid pretreatment (Route-1); (b) ammonium hydroxide and acetic acid pretreatment (Route-2); (c) sodium hydroxide and sulfuric acid pretreatment (Route 3); (d) sodium hydroxide and acetic acid pretreatment

(Route-4) 


\section{Economic Evaluation Method}

The economic simulation of nitrocellulose production was carried out using SuperPro Designer 9.0. The economic paremeters of such as return of investment (ROI), payback period (PBP), net present value (NPV), and internal rate of return (IRR) were evaluated. The following assumptions and constants were used in calculating economic evaluation:

- The year for cost analysis was 2019.

- United Stated Dollars used as currency.

- Two years for plant construction and 20 years for plant operation.

- The total investment cost was obtained from loan with 10\% compound interest per year.

- The plant capacity was 200 tons of POEFBs/year .

- MACRS method was used as depreciation method with 15 years period.

- Minimum Acceptable Rate of Return was 11\%.

- $25 \%$ tax was used.

- The price of POEFBs was US\$ 10/ton which based on Reeb et al. ${ }^{11}$ POEFBs price average calculation.

- The price of nitrocellulose was US\$ 3,000/ton which based on Hebei Yanxi Chemical ${ }^{12}$ price.

- The price of electricity was US\$ $0.1 / \mathrm{kW}-\mathrm{h}$ which based on Indonesian Electricity Company ${ }^{13}$

- The price of labor was US\$ $144 /$ month which based on average minimun salary in Indonesia ${ }^{14}$

Total Capital Investment (TCI) can be formulated:

$$
\text { TCI = Fixed Capital Investment }+ \text { Startup Cost }+ \text { Working Capital }
$$

where

$$
\text { Fixed Capital Investment }(\mathrm{FCI})=1.2 \mathrm{x} \text { Equipment Cost }
$$

and

$$
\text { Startup Cost }=5 \% \text { x Fixed Capital Investment }
$$

Equipment Cost and Working Capital were calculated from SuperPro simulation.

Total Operating Cost can be formulated:

$$
\begin{gathered}
\text { TOC }=\text { Raw Material Cost }+ \text { Labor-Dependent Cost }+ \text { Facility-Dependent Cost }+ \\
\text { Laboratory/Quality Control Cost }+ \text { Waste Treatment Cost }
\end{gathered}
$$

where Raw Material Cost, Labor-Dependent Cost, Facility-Dependent Cost, Laboratory/Quality Control Cost, and Waste Treatment Cost were calculated from SuperPro simulation.

The yield of nitrocellulose from the POEFBs on a mass basis $\left(\mathrm{Y}_{\mathrm{N}}\right)$ was defined as the ratio of the nitrocellulose mass in product stream to POEFBs mass of plant capacity (200 tons of POEFBs/year):

$$
Y_{N}\left(\frac{\text { mass }}{\text { mass }}\right) \%=\frac{\text { Nitrocellulose mass in product stream }}{200 \text { tons of POEFBs/year }} \times 100 \%
$$


Return On Investment (ROI) was defined as the ratio of average profit (Np) to Total Capital Investment (TCI):

$$
R O I=\frac{N p}{\mathrm{TCI}} \times 100 \%
$$

Payback Period (PBP) identified as the project time required for payback. It was defined as the ratio of Fixed Capital Investment (FCI) to Annual Cash Flow (Aj):

$$
P B P=\frac{F C I}{A j}
$$

The net present value (NPV) is the total of the present worth of all cash flws minus the present worth of all capital investments, and Internal Rate of Return (IRR) is discount rate which make NPV is zero. The formula and calculation method of NPV and IRR was based on Peters et al. ${ }^{15}$

\section{Results and Discussion}

\section{Economic Evaluation Result}

Economic evaluation from Superpro Designer simulation were based on SuperPro Designer 9.0 chemical database ${ }^{16}$ with some adjustments which can be seen in Table 2 . The results of economic evaluation from Superpro Designer simulation in various pretreatment processes of POEFBs to produce nitrocellulose can be seen in Table 3.

Table 2. Parameter Adjustments in SuperPro Designer 9.0 Simulation

\begin{tabular}{lll}
\hline Parameters & Value & Reference \\
\hline POEFBs price & US\$ 10/ton & {$[11]$} \\
Nitrocellulose price & US\$ 3,000/ton & {$[12]$} \\
Electricity price & US\$ $0.1 / \mathrm{kW}-\mathrm{h}$ & {$[13]$} \\
Labor price & US\$ $144 /$ month & {$[14]$} \\
\hline
\end{tabular}

Table 3. Economic Evaluation of Nitrocellulose Production

\begin{tabular}{cllll}
\hline Parameters & Route - 1 & Route - 2 & Route - 3 & Route $-\mathbf{4}$ \\
\hline Equipment Cost & $2,017,000$ & $1,931,000$ & $1,772,000$ & $1,701,000$ \\
Fixed Capital Investment & $2,420,400$ & $2,317,200$ & $2,126,400$ & $2,041,200$ \\
Startup Cost & 121,020 & 115,860 & 106,320 & 102,060 \\
Working Capital & 6,000 & 8,000 & 12,000 & 14,000 \\
Total Capital Investment (US\$) & $2,547,420$ & $2,441,060$ & $2,244,720$ & $2,157,260$ \\
Total Revenue (US\$/year) & 886,983 & 830,894 & 450,024 & 429,873 \\
Raw Material & 2,000 & 2,000 & 35,000 & 35,000 \\
Labor-Dependent & 33,000 & 35,000 & 31,000 & 33,000 \\
Facility-Dependent & 4,000 & 4,000 & 4,000 & 3,000 \\
Laboratory/Quality & 2,000 & 2,000 & 2,000 & 2,000 \\
Control & 29,000 & 47,000 & 68,000 & 82,000 \\
Waste Treatment & & & & \\
Total Operating Cost (US\$/year) & 70,000 & 90,000 & 139,000 & 154,000 \\
Heating Agent & 11,242 & 39,702 & 10,453 & 31,325 \\
Cooling Agent & 17,879 & 7,612 & 57,668 & 50,183 \\
\hline
\end{tabular}




\begin{tabular}{lllll}
\hline Parameters & Route - 1 & Route - 2 & Route $-\mathbf{3}$ & Route -4 \\
\hline $\begin{array}{l}\text { Total Utility Cost (US\$/year) } \\
\text { Yield }\end{array}$ & 29,121 & 47,314 & 68,121 & 81,507 \\
(nitrocellulose/POEFBs)(\%) & 65 & 64 & 65 & 64 \\
ROI (\%) & 11.49 & 10.21 & -2.16 & -2.95 \\
PBP (years) & 5.85 & 6.35 & 36.72 & 53.23 \\
NPV (US\$) & 442,427 & 172,977 & $-2,052,963$ & $-2,110,825$ \\
IRR (\%) & 13.35 & 11.97 & -3.70 & -5.07 \\
\hline
\end{tabular}

In Table 3, the economic parameters in Route-3 and Route-4 were not profitable. On the other hand, Route- 1 and Route- 2 was profitable process to produce nitrocellulose. Route-1 was the most profitable production process route which produce economic parameter values such as ROI, PBP, NPV and IRR around 11.49\%, 5.85 years, US \$ 442,427, and $13.35 \%$. Process flow diagram of Route- 1 can be seen in Figure 2.

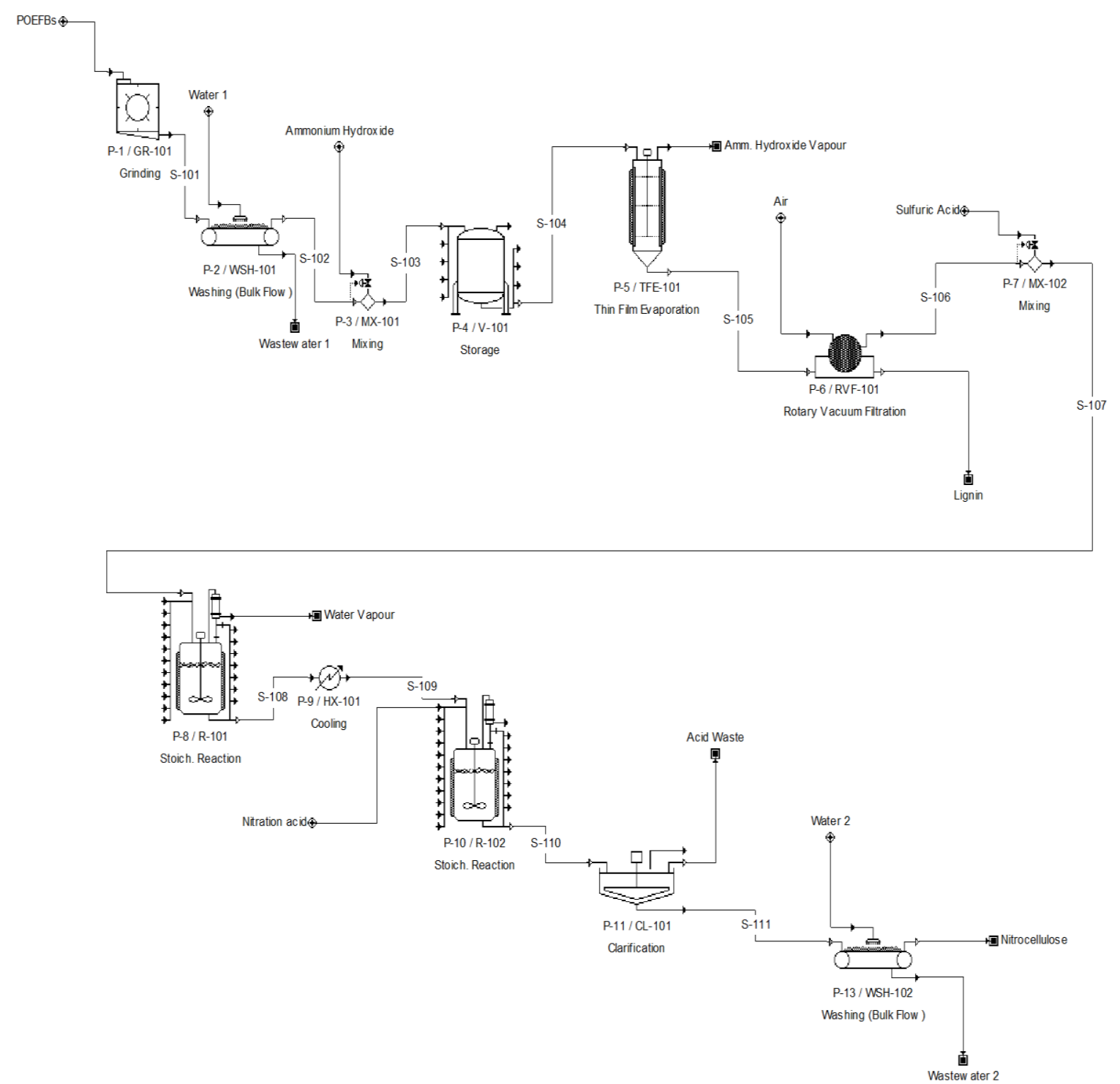

Figure 2: Process flow diagram of ammonium hydroxide and sulfuric acid pretreatment (Route-1) 


\section{Effect of Pretreatments in Economic Evaluation}

The combination of various pretreatment methods has an effect on initial process flow in the nitrocellulose production. In Route- 3 and Route-4, alkaline pretreatment was carried out using sodium hydroxide. Sodium hydroxide is an alkali compound that commonly used to remove lignin in lignocellulose biomass. Alkaline pretreatment triggers the saponification of intermolecular ester bonds crosslinking xylan hemicelluloses and lignin ${ }^{17}$. The effectiveness of sodium hydroxide in cellulose purification can be seen in the study of Triwahyuni et al. ${ }^{7}$. However, the pretreatment process with sodium hydroxide is an expensive process because of the high price of sodium hydroxide and the high temperature pretreatment used, so it will increase plant operating costs. Besides that, the lignin that produced in this process was also difficult to recover. Therefore, based on economic evaluation, Route-3 and Route-4 were not profitable.

Ammonium hydroxide pretreatment was an alkaline pretreatment that applied to Route- 1 and Route-2. The delignification using ammonium hydroxide was done by immersion method according to Gozan et al. ${ }^{3}$. The advantage of this method was that lignin and ammonium hydroxide can be recovered due to the low boiling point of ammonium hydroxide $\left( \pm 27^{\circ} \mathrm{C}\right)$. Therefore, the operational costs of pretreatment using ammonium hydroxide compounds are lower than sodium hydroxide.

The difference in Route- 1 and Route- 2 was in the acid pretreatment. Acid in the lignocellulose biomass pretreatment process has function to produce hydrogen ions in water which function to break the bonds that exist in lignocellulose biomass. In Route-1, sulfuric acid is used as acid pretreatment process. Sulfuric acid is the most commonly acid for pretreatment and hydrolysis of biomass, and sulfuric acid solution and POEFBS from the pretreatment can be used directly into the nitration reaction stage. On the other side, acetic acid is also an acid that can be used for the pretreatment process. Some advantages of acetic acid pretreatment such as dissolve the lignin fragment, the ability of acetic acid to do hemicellulose deacetylation and acetic acid can be recovered by simple distillation ${ }^{18}$.

Based on table 2, Route-1 and Route-2 had differences in total capital investment, total revenue and total operating cost. Total capital investment in Route-1 was higher than Route- 2 because in the Route- 1 after the acid pretreatment process cooling process was needed before the nitration process. The difference in total revenue in Routes- 1 and Routes- 2 can be caused by the yield of the products. On the other side, the difference in operational costs for the sulfuric acid and acetic acid pretreatment was based on the operating temperature and acid concentration. The sulfuric acid pretreatment was carried out at $120^{\circ} \mathrm{C}$ with $2 \%$ acid concentration, but acetic acid pretreatment was carried out at $160^{\circ} \mathrm{C}$ with $30 \%$ acid concentration. Therefore, from the economic evaluation of operational costs, it was found that the pretreatment operating costs using sulfuric acid was lower than acetic acid.

\section{Conclusions}

Techno-economic evaluation of nitrocellulose production with various types of alkaline and acid pretreatments was investigated. The pretreatment of POEFBs with alkaline and acid was used to purify cellulose as raw materials for nitrocellulose. The alkaline and acid pretreatments can be classified into 4 process routes such as ammonium hydroxide and sulfuric acid pretreatment (Route-1), ammonium hydroxide and acetic acid pretreatment (Route-2), sodium hydroxide and sulfuric acid pretreatment (Route-3), and sodium hydroxide and acetic acid pretreatment (Route-4). The results showed that alkali pretreatment with sodium hydroxide did not produce profitable process because of the high operational cost. On the other hand, ammonium hydroxide pretreatment had lower operational costs than sodium hydroxide 
pretreatment because of simpel soaking method. Sulfuric acid and acetic acid are the effective acid for pretreatment and hydrolysis of biomass. Based on the economic evaluation, the operational costs of sulfuric acid pretreatment were lower than acetic acid pretreatment. Therefore, Route-1, the pretreatment route using ammonium hydroxide and sulfuric acid treatment was the most profitable route with the economic parameters such as ROI, PBP, NPV and IRR were $11.49 \%, 5.85$ years, US\$ 442,427 , and $13.35 \%$.

\section{Acknowledgement}

Authors would like to thank to Institut Teknologi Sumatera for providing the research grant (No:B/328/IT9.C1/PT.01.03/2019) through “Hibah Penelitian ITERA SMART 2019”.

\section{References}

[1] K. Pertanian, Outlook Kelapa Sawit Komoditas Pertanian Subsektor Perkebunan, Indonesia, 2016 [in Bahasa].

[2] M. Karina, H. Onggo, A.H.D. Abdullah, and A. Syampuradi, "Effects of oil palm empty fruit bunch fiber on the physical and mechanical properties of fiber glass reinforced polyester resin," Journal of Biological Sciences, Vol. 8, No. 1, pp. 101-106, 2008.

[3] M. Gozan, J.R.H. Panjaitan, D. Tristantini, R. Alamsyah, and Y.J. Yoo, "Evaluation of separate and simultaneous kinetic parameters for levulinic acid and furfural production from pretreated palm oil empty fruit bunches," International Journal of Chemical Engineering, No. 1920180, pp. 1-12, 2018.

[4] F.T. Seta, S. Sugesty, and T. Kardiansyah, "Pembuatan nitroselulosa dari berbagai pulp larut komersial sebagai bahan baku propelan,” Jurnal Selulosa, Vol. 4, pp. 97-106, 2014 [in Bahasa].

[5] Miranda, Padil and Yelmida, Pembuatan Nitroselulosa Dari Selulosa - A limbah Pelepah Sawit Dengan Variasi Waktu Nitrasi Dan Rasio Bahan Baku Terhadap Asam Penitrasi, Thesis (Bachelor's), Riau University, Pekanbaru, Indonesia, 2013 [in Bahasa].

[6]. Grand View Research, Nitrocellulose Market Size, Share \& Trends Analysis Report by Application (Printing Inks, Automotive Paints, Wood Coatings, Leather Finishes, Nail Varnishes), by Region, and Segment Forecasts, 2018-2024, 2018 [Online]. Available: www.grandviewresearch.com [Accessed: December 2018].

[7] E. Triwahyuni, Muryanto, Y. Sudiyani, and H. Abimanyu, "The effect of substrate loading on simultaneous saccharification and fermentation process for bioethanol production from oil palm empty fruit bunches," Energy Procedia, Vol. 68, pp. 138-146, 2015.

[8] T.Y. Ying, L.K. Teong, W.N.W. Abdullah, and L.C. Peng, "The effect of various pretreatment methods on oil palm empty fruit bunch (EFB) and kenaf core fibers for sugar production," Procedia Environmental Sciences, Vol. 20, pp. 328-335, 2014.

[9] T. Mouthier, M.M. Appeldoorn, H. Pel, H.A. Schols, H. Gruppen, and M.A. Kabel, "Corn stover lignin is modified differently by acetic acid compared to sulfuric acid," Industrial Crops \& Products, Vol. 121, pp. 160-168, 2018.

[10] Y.M. Setiadi, Y. Mulyadi, and B. Kusmartono, "Optimasi pembuatan nitroselulosa dari daun nanas dengan proses delignifikasi dalam upaya mewujudkan sumber energi bersih dan terbarukan," Prosiding Seminar Nasional XII Rekayasa Teknologi Industri dan Informasi 2017 Sekolah Tinggi Teknologi Nasional Yogyakarta, Yogyakarta, Indonesia, pp. 304-309, 2017 [in Bahasa].

[11] C.W. Reeb, T. Hays, R.A. Venditti, R. Gonzalez, and S. Kelley, "Supply chain analysis, delivered cost, and life cycle assessment of oil palm empty fruit bunch biomass for green chemical production in Malaysia," Bioresources, Vol. 9, No. 3, pp. 5385-5416, 2014. 
[12] Hebei Yanxi Chemical, Pabrik Pasokan 99\% Kemurnian Untuk Cat Dan Coating, 2021 [Online]. Available: https://indonesian.alibaba.com [Accessed: May 2021].

[13] PT Perusahaan Listrik Negara (Persero), "Tarif Listrik Triwulan 12021 Tidak Naik," 2021 [Online]. Available: https://web.pln.co.id [Accessed: May 2021] [in Bahasa].

[14] Badan Pusat Statistik, Data from: Upah Minimum Regional/Provinsi (UMR/UMP) dan Rata - Rata Nasional per Tahun (Dalam Rupiah) [Data set], Badan Pusat Statistik [Online]. Available: https://www.bps.go.id [Accessed: May 2021] [in Bahasa].

[15] M.S. Peters, K.D. Timmerhaus, and R.E. West, Plant Design and Economics for Chemical Engineers, $5^{\text {th }}$ Edition, McGraw-Hill, New York, United States, 2003.

[16] Inteligen, Inc., SuperPro Designer 9.0 Academic Site Edu, Retrieved from https://www.intelligen.com/

[17] Y. Sun, and J. Cheng, "Hydrolysis of lignocellulosic materials for ethanol production: A review," Bioresource Technology, Vol. 83, pp. 1-11, 2002.

[18] X. Zhao, J. Wen, H. Chen, and D. Liu, "The fate of lignin during atmospheric acetic acid pretreatment of sugarcane bagasse and the impacts on cellulose enzymatic hydrolyzability for bioethanol production," Renewable Energy, Vol. 128, pp. 200-209, 2018. 